\title{
Clean Metals Production by Solid Oxide Membrane Electrolysis Process
}

\author{
Xiaofei Guan ${ }^{1,2,3} \cdot$ Uday B. Pal $^{1,2} \cdot$ Yihong Jiang ${ }^{2} \cdot$ Shizhao Su ${ }^{2}$
}

Published online: 26 February 2016

(C) The Minerals, Metals \& Materials Society (TMS) 2016

\begin{abstract}
This paper reviews a clean metals, production technology that utilizes an oxygen-ion-conducting solid oxide membrane (SOM) to directly electrolyze metal oxides dissolved in a non-consumable molten salts. During the SOM electrolysis process, the desired metal such as magnesium, aluminum, silicon, or a rare earth is produced at the cathode while pure oxygen gas evolves at the anode. Compared with current state-of-the-art metal production processes, such as a chloride-based electrolysis process for magnesium production and the Hall-Héroult process for smelting aluminum, the SOM process brings various advantages such as simplified design, lower cost, lower energy use, and zero emissions. It provides a general route for producing various metals and has great potential to replace current metals, production processes. This paper examines the past and present progress of the SOM process, the challenges faced in commercialization, and the directions for future work.
\end{abstract}

Keywords Solid oxide membrane electrolysis - Green metals production $\cdot$ Cost-effective

The contributing editor for this article was Bart Blanpain.

Uday B. Pal

upal@bu.edu

1 Department of Mechanical Engineering, Boston University, Boston, MA 02215, USA

2 Division of Materials Science and Engineering, Boston University, Brookline, MA 02446, USA

3 Present Address: John A Paulson School of Engineering and Applied Sciences, Harvard University, Cambridge, MA 02138, USA

\section{Introduction}

Today's metals industry is a major consumer of carbonbased energy and generates a significant amount of pollutants including greenhouse gases (GHG) [1,2]. The societal impetus to lower energy consumption and GHG emissions provides motivation for the development of clean technologies that could reshape the metals industry and enable environmental sustainability. To meet this challenge, we are developing a cost-effective, energy-efficient, and zero-emissions solid oxide membrane (SOM)based electrolysis process for the production of technologically critical metals. The SOM-based electrolysis technology would produce metals (Me) from their respective oxides $\left(\mathrm{MeO}_{x}\right)$ by the direct electrolysis reaction: $\mathrm{MeO}_{x} \rightarrow \mathrm{Me}$ (cathode) $+x / 2 \mathrm{O}_{2}$ (anode), where $x$ is the stoichiometric amount of oxygen in the metal oxide.

Specifically, in the metal product value chain from mined ores $\rightarrow$ ore concentrates $\rightarrow$ oxides $\rightarrow$ metals $\rightarrow$ alloys $\rightarrow$ finished products, the most energy-intensive step is usually the oxide to metal conversion. This step typically requires carbothermic, metallothermic, or halide reduction of the oxides. For example, in primary $\mathrm{Mg}$ production, around $85 \%$ of the world's $\mathrm{Mg}$ is produced via the Pidgeon process where oxide ores (e.g., $\mathrm{CaMgO}_{2}$ ) are reduced by ferrosilicon through silicothermic reactions [3]. The Pidgeon process is energy and resource intensive requiring nearly double the energy required by electrochemical processes [4]. An alternative industrial method for $\mathrm{Mg}$ production is the $\mathrm{MgCl}_{2}$ electrolysis process which starts with high-purity $\mathrm{MgO}$ and requires chlorination and energy-intensive chloride dehydration $[5,6]$. The process emits harmful chlorine, polychlorinated biphenyls (PCBs), and other contaminants [7,8]. Currently, over $90 \%$ of the silicon $(\mathrm{Si})$ production starts with carbothermic reduction 
of silicon oxide to metallurgical-grade Si followed by its purification that involves multiple energy-intensive steps such as chlorination, distillation, and chemical vapor deposition on a hot wire substrate [9]. The low-melting point rare earth elements, such as lanthanum, cerium, and neodymium, have been produced by fused salt electrolysis of chlorides on a commercial scale, which requires chlorination of the rare earth oxides as well [10]. The Ames process for the production of rare earth metals typically uses calcium metal to reduce rare earth fluoride that is prepared from high-purity oxide via reaction with a fluorine bearing compound such as HF [11]. In primary aluminum production via the Hall-Héroult process, although $\mathrm{Al}_{2} \mathrm{O}_{3}$ is directly electrolyzed, the electricity use is more than double the reaction enthalpy due to heat losses through frozen cryolite sidewalls [12]. In addition, the hot $\mathrm{CO}_{2}$ gas emitted from the graphite anodes contains not only HF, which renders heat recovery from exiting gas impractical, but also perfluorocarbons, powerful GHG with global warming potential of 6500-9200 times of $\mathrm{CO}_{2}$ [13].

Compared with these traditional methods of extractive metallurgy, the SOM process brings various advantages such as simplified design, lower cost, lower energy use, and zero emissions. The SOM process features the utilization of an oxygen-ion-conducting membrane, typically made of yttria-stabilized zirconia (YSZ), for directly electrolyzing metal oxides. Since the late 1960s, researchers have recognized and investigated the use of zirconia solid electrolyte for metals production and refining [14-18]; however, limited progress was achieved due to the poor stability of the zirconia membrane, low current density, and lack of an appropriate current collector assembly. A decade ago, Pal's pioneering work on new molten salt compositions increased solubility of many oxides, e.g., $\mathrm{CaF}_{2}-\mathrm{MgF}_{2}$ eutectic molten salt dissolves $\sim 10 \mathrm{wt} \% \mathrm{MgO}$, decreased zirconia corrosion rate, and has generated new interest in commercialization of the process for metals production $[19,20]$. The SOM process has been applied to reduce various metal oxides or oxide compounds to the respective metals or alloys, including $\mathrm{Mg}$ [19, 21-26], Al [27], Ti [28], $\mathrm{Ca}[29,30], \mathrm{Fe}$ [22], $\mathrm{Cu}[31], \mathrm{Ta}$ [20], $\mathrm{Cr}[20], \mathrm{Nb}$ [20, 32], Yb [33], Nd, Pr, Dy, Si [34], $\mathrm{CeNi}_{5}$, and $\mathrm{La}_{x}$ $\mathrm{Ce}_{1-x} \mathrm{Ni}_{5}$ [35], Ti-Fe alloy [36, 37], Ti-Si intermetallics $[38,39]$. A series of the metals produced by the SOM process are highlighted in the periodic table presented in Fig. 1a. A brief survey of the applications of only some technologically important metals is shown in Fig. 1b; lightweight metals, such as $\mathrm{Mg}, \mathrm{Al}$, and $\mathrm{Ti}$ are widely used as structural materials in automobiles and aircrafts due to their excellent strength-to-weight ratios, [41, 42] rare earth metals, such as $\mathrm{Nd}$ and Dy are used in permanent strong magnets for wind turbines, medical devices, and hybrid cars, [43, 44] semi-conductors, such as $\mathrm{Si}$ and $\mathrm{Ge}$ are widely used in photovoltaics and electronic devices, [45] refractory metals, such as Ta are widely used in surgical implants and electrical capacitors [31, 40].

\section{Description of the SOM Process}

The SOM process electrolyzes metal oxides dissolved in a pre-selected non-consumable molten flux and directly produces the desired metals as well as pure oxygen gas as a valueadded byproduct. A schematic of the SOM process is shown in Fig. 2. An oxygen-ion-conducting SOM made of YSZ separates an inert anode from a molten flux and a cathode. At the experimental temperature range from 1073 to $1573 \mathrm{~K}$ (800-1300 ${ }^{\circ} \mathrm{C}$ ), when the applied electric potential between the electrodes exceeds the dissociation potential of the metal oxide $(\mathrm{MeO})$, the metal $(\mathrm{Me})$ is reduced at the cathode and oxygen ions migrate through the SOM and are oxidized at the inert anode producing pure byproduct oxygen gas.

The key component of this electrolysis process is the anode assembly consisting of the SOM and the inert anode. First, the SOM selectively conducts only oxygen ions. This avoids dissociation of molten fluoride or chloride salts at even high applied potentials, leading to high current density and high Faradaic current efficiency. The current density is typically defined as the ratio of the passing current to the effective area of the SOM/flux interface. The SOM also gives rise to a high-purity oxygen product at the inert anode with no HF, CO, or perflurocarbons. Second, the SOM prevents the pure oxygen gas from back-reaction with the reduced metal. This allows for an inert or reducing environment in the molten flux and the cathode, and thus maintains a high metal product yield. To the best of our knowledge, no other anode technology can achieve these results because all other anodes produce gases in the electrolyte that react with the metals produced and the electrodes, or corrode the reaction chamber.

In the following subsections, we aim to provide a thorough discussion on the three components of a SOM electrolysis cell: anode assembly, cathode, and flux electrolyte. We will also provide insights into experimental design and materials selection strategy.

\section{Anode Assembly}

The anode assembly consists of a SOM, an anode, and an anode current collector. The SOM can be made of a variety of oxides such as rare earth or alkaline earth-doped zirconia-, ceria-, hafnia-, or thoria-based materials [46]. YSZ is the most studied material as the membrane for SOM electrolysis, and it shows high ionic conductivity [47] and excellent stability in contact with well-tailored molten flux electrolytes. 
Fig. 1 a Metals produced to date by the SOM electrolysis process (highlighted in green in the chemical periodic table).

b A brief survey of the applications of some metals produced by SOM electrolysis process. While there is overlap with the applications of many of these materials, they are grouped to demonstrate the versatility of SOM process. The inset figure for Ta surgical implant is reproduced with permission from InTech. It was orginally published in reference [40] under CC BY 3.0 license (Color figure online) (a)

\begin{tabular}{|c|c|c|c|c|c|c|c|c|c|c|c|c|c|c|c|c|c|}
\hline $\mathrm{H}$ & \multicolumn{16}{|c|}{ Periodic Table of the Elements } & \multirow{2}{*}{\begin{tabular}{|l}
$\mathrm{He}$ \\
$\mathrm{Ne}$
\end{tabular}} \\
\hline Li & $\mathrm{Be}$ & & & & & & & & & & & $\mathbf{B}$ & $\mathrm{C}$ & $\mathbf{N}$ & $\mathrm{O}$ & $F$ & \\
\hline $\mathrm{Na}$ & Mg & & & & & & & & & & & $\mathrm{Al}$ & Si & $\mathbf{P}$ & $\mathbf{S}$ & $\mathrm{Cl}$ & $\mathrm{Ar}$ \\
\hline K & $\mathrm{Ca}$ & Sc & $\mathrm{Ti}$ & v & $\mathrm{Cr}$ & $\mathbf{M n}$ & $\mathrm{Fe}$ & Co & $\mathrm{Ni}$ & $\mathrm{Cu}$ & $Z n$ & $\mathrm{Ga}$ & $\mathrm{Ge}$ & As & Se & $\mathrm{Br}$ & $\mathrm{Kr}$ \\
\hline $\mathrm{Rb}$ & Sr & $\mathbf{Y}$ & $\mathrm{Zr}$ & $\mathrm{Nb}$ & Mo & Tc & $\mathbf{R u}$ & $\mathbf{R h}$ & $\mathbf{P d}$ & $\mathrm{Ag}$ & Cd & In & Sn & $\mathrm{Sb}$ & Te & I & $\mathrm{Xe}$ \\
\hline Cs & $\mathrm{Ba}$ & La & Hf & $\mathrm{Ta}$ & $\mathbf{w}$ & $\operatorname{Re}$ & Os & Ir & Pt & Au & $\mathrm{Hg}$ & $\mathrm{Ti}$ & $\mathbf{P b}$ & $\mathrm{Bi}$ & Po & At & $\mathbf{R n}$ \\
\hline $\mathrm{Fr}$ & $\mathbf{R a}$ & $A C$ & Uno & Unp & Unh & Uns & Uno & Une & Unn & & & & & & & & \\
\hline
\end{tabular}

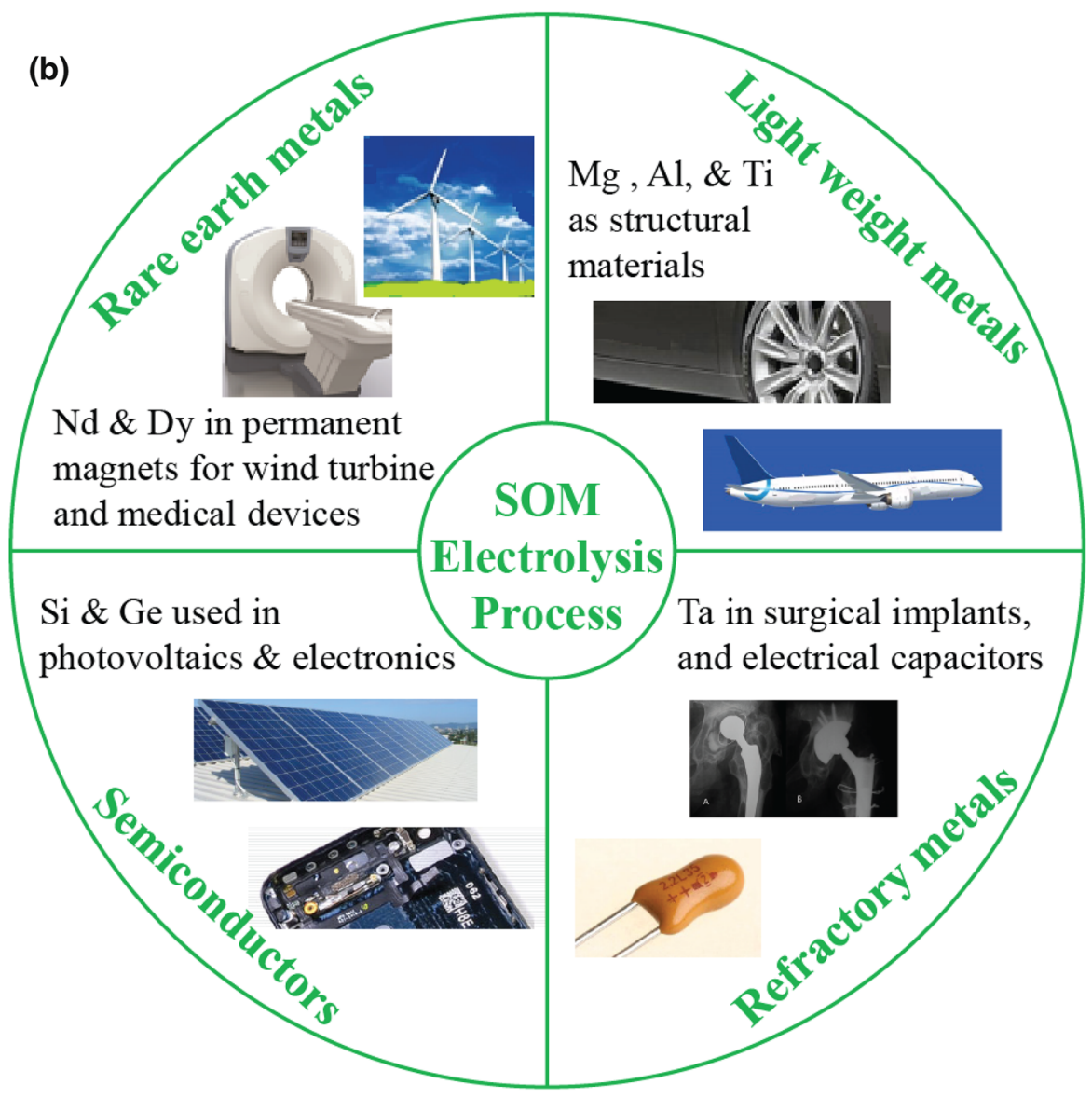

At the anode of a SOM electrolysis cell, oxygen anions are oxidized to pure $\mathrm{O}_{2}, \mathrm{H}_{2} \mathrm{O}$, or $\mathrm{CO}$, depending on the anode materials or fuel supply. When a carbon rod submerged in liquid metal anode $(\mathrm{Ag}, \mathrm{Sn}$, or $\mathrm{Cu})$ [31], or a
$\mathrm{Mo} / \mathrm{Fe}-\mathrm{Cr}-\mathrm{Al}$ wire inserted into carbon-saturated liquid metal anode ( $\mathrm{Sn}$ or $\mathrm{Cu}$ ) [37] is used as an anode current collector, the oxygen anions are oxidized by the carbon rod to form $\mathrm{CO}$ at the operating temperature range of 


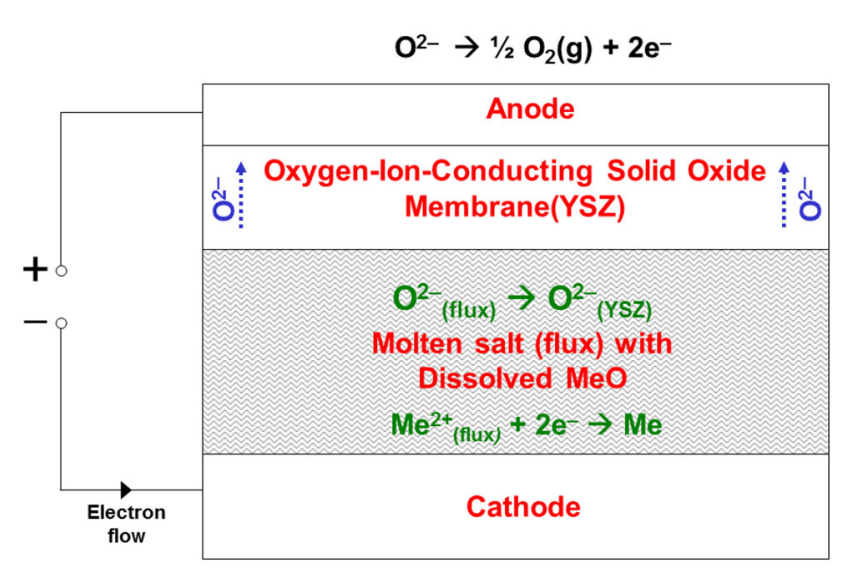

Fig. 2 Schematic diagram of a SOM cell for metal production

$1273-1573 \mathrm{~K}$. When a molybdenum tube submerged in a liquid metal anode ( $\mathrm{Ag}, \mathrm{Sn}$, or $\mathrm{Cu}$ ) is used as an anode current collector and hydrogen or natural gas is passed through the molybdenum tube into the liquid metal anode, the gas oxidizes the oxygen anions. This process consumes a lot of hydrogen or natural gas and produces water vapor or a mixture of water vapor and $\mathrm{CO}_{2}$, respectively. By supplying a reductant at the anode, the electrical energy requirement can be lowered.

In order to produce pure $\mathrm{O}_{2}$ as a valuable byproduct, it is critical to develop an inert anode and an inert current collector that maintain high electronic conductivity but do not react with $\mathrm{O}_{2}$ under the prevailing experimental conditions.

Liquid silver is electrically conductive and thermodynamically stable in oxygen above its melting point $(1235 \mathrm{~K})$ and therefore allows $\mathrm{O}_{2}$ gas to freely evolve. In addition, liquid silver has high oxygen solubility, diffusivity [48], and also wets the YSZ membrane. All these factors make liquid silver more appropriate as an inert anode, compared with a much less conductive porous cermet composed of a stabilized zirconia and an electronic oxide stable under an oxygen environment [e.g., strontiumdoped lanthanum manganite (LSM), and lanthanum strontium cobalt ferrite (LSCF)] [46] Non-consumable liquid $\mathrm{Ag}$ is therefore selected as the inert anode material for SOM experiments conducted in the temperature range of $1273-1573 \mathrm{~K}$. In some special cases where SOM electrolysis is needed to be performed at temperatures below the melting point of liquid Ag, the porous cermet composed of zirconia and LSM (or LSCF) can still be used as the inert anode.

An inert anode current collector needs to be immersed in the liquid silver anode and provide good electrical connection between the liquid silver anode and the DC power supply. The inert anode current collector must have the following properties: (a) good physical and chemical stabilities in $\mathrm{O}_{2}$ and liquid silver at the operating temperature; (b) excellent thermal shock resistance and mechanical robustness; and (c) high electrical conductivity from ambient temperature $(293 \mathrm{~K})$ to the operating temperature (1273-1573 K).

Previous work has reported that iridium wire immersed in liquid silver is suitable as an inert anode current collector in SOM electrolysis for $\mathrm{O}_{2}$ evolution at $1423 \mathrm{~K}$ [46]. However, the high price and the scarcity of iridium limit its large-scale use. Recently, Guan et al. have developed a novel inert anode current collector design (Fig. 3) [21]. The current collector incorporates a short piece of sintered strontium-doped lanthanum manganite $\left(\mathrm{La}_{0.8} \mathrm{Sr}_{0.2} \mathrm{MnO}_{3-\delta}\right.$ or LSM) bar and an oxidation resistant Inconel 601 alloy rod with a liquid silver contact in between the two. LSM is one of the most investigated air electrode material in solid oxide fuel cell [49]. It is therefore also a material of choice for the inert anode current collector in SOM experiments because of its tolerance to high temperature and $\mathrm{O}_{2}$ environment while maintaining relatively high electrical conductivity and very low oxygen ion conductivity. The Inconel 601 alloy rod has an adequate high-temperature oxidation resistance and maintains very high conductivity from room temperature to the operating temperature. A small amount of liquid silver wets and electrically connects both the LSM bar and the Inconel 601 alloy rod and minimizes the contact resistances. In this design, an open-ended alumina tube (sleeve) protected the Inconel rod from oxidation in the high-temperature pure oxygen environment. A combination of LSM powders and alumina paste applied between the alumina tube and the LSM bar formed a tight seal preventing oxygen from reaching the Inconel rod. This design of the inert anode current collector (Fig. 3) takes advantages of the respective properties of the LSM bar, the Inconel 601 alloy rod, and the liquid silver contact. A 13-hour stability test shows that the electrical resistance of a LSM-Inconel current collector has a stable value of $0.12 \Omega$, which contributes only around $1 / 5$ of the total ohmic resistance of a SOM cell for Mg production [21]. The LSMInconel current collector was evaluated in many SOM electrolysis experiments. Pure oxygen gas evolution was observed once the liquid silver anode was saturated with oxygen. Since the inert anode and the current collector are inside the SOM (YSZ) tube, they do not react with the molten flux or the cathode environment. Thus the same design can be used to produce all desired metals. It has been shown through many successful electrolysis experiments that the SOM tube, with the inert liquid silver anode and the LSM-Inconel current collector arrangement can be employed to dissociate many metal oxides and produce oxygen gas as a valuable byproduct. A scanning electron microscope (SEM) was used to evaluate the stability of the inert anode current collector after the electrolysis. Figure $3 \mathrm{~d}$ and e show SEM images of the Alumina-LSM interface along cross section (I) (see 


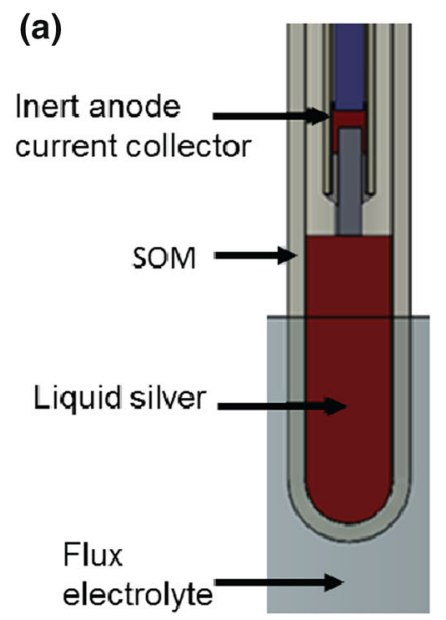

(d)

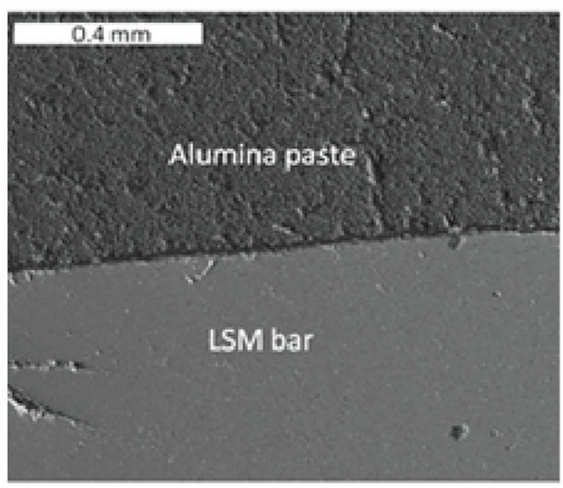

Fig. 3 a Schematic of SOM anode assembly; b Schematic of LSMInconel inert anode current collector; c a photograph of the asprepared inert anode current collector; d SEM image of aluminaLSM interface along section (I) in c, and e SEM image of Ag-LSM

Fig. 3c) and the Ag-LSM interface along cross section (II), respectively. The LSM-Inconel current collector was intact after a typical SOM electrolysis experiment, highlighting its durability and reusability.

\section{Cathode}

The cathode material on which the desired metal is reduced is selected depending on the metal product desired. The primary cathode material can be either:

- an inert metal if the desired metal is produced in the form of a gas and subsequently condensed in a separate chamber (e.g., $\mathrm{Mg}$ (g) produced on a steel cathode) [19, 21, 50],

- an inert electronic conductor such as $\mathrm{TiB}_{2}$ (e.g., for $\mathrm{Al}$ production) $[27,51]$,

- the desired metal itself (e.g., Ta) [20, 31], (e)

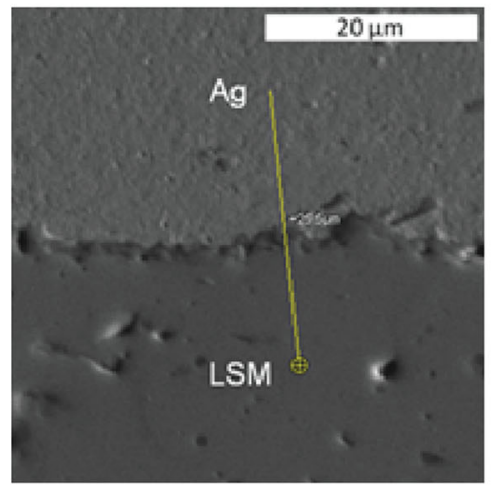

interface along section (II) in $\mathbf{c}$ after the electrolysis experiment. The yellow line in e perpendicular to the Ag-LSM interface serves as a guide for eye. Reproduced with permission from Guan et al. [21]. Copyright 2013, The Electrochemical Society (Color figure online)

- another metal if an alloy with that metal is desired (e.g., $\mathrm{Si}$ or $\mathrm{Nd}$ is produced on an iron cathode to form $\mathrm{Fe}-\mathrm{Si}$ or Fe-Nd alloy, respectively),

- another metal from which the desired metal can be crystallized out in a pure form (e.g., Si crystallized from a liquid $\mathrm{Sn}$ cathode) [34, 52], or

- the oxide of the desired metal in the form of a compressed pellet (e.g., Ta, $\left.\mathrm{CeNi}_{5}, \mathrm{Ti}-\mathrm{Si}, \mathrm{Ti}-\mathrm{Fe}\right)[20$, $31,35,36,39]$.

Specific examples of cathode designs for different metal products are given and discussed in detail in "Applications of SOM Process" Section.

\section{Flux Electrolyte}

The flux electrolyte is adjacent to the SOM tube. For the SOM electrolysis process to run for a long period at high current density and high Faradaic efficiency, the flux 
Fig. 4 Absolute value of the standard Nernst potential $\left(E_{\mathrm{N}}^{0}\right)$ for each reaction at the temperature range from 1273 to $1573 \mathrm{~K}\left(1000-1300{ }^{\circ} \mathrm{C}\right)$

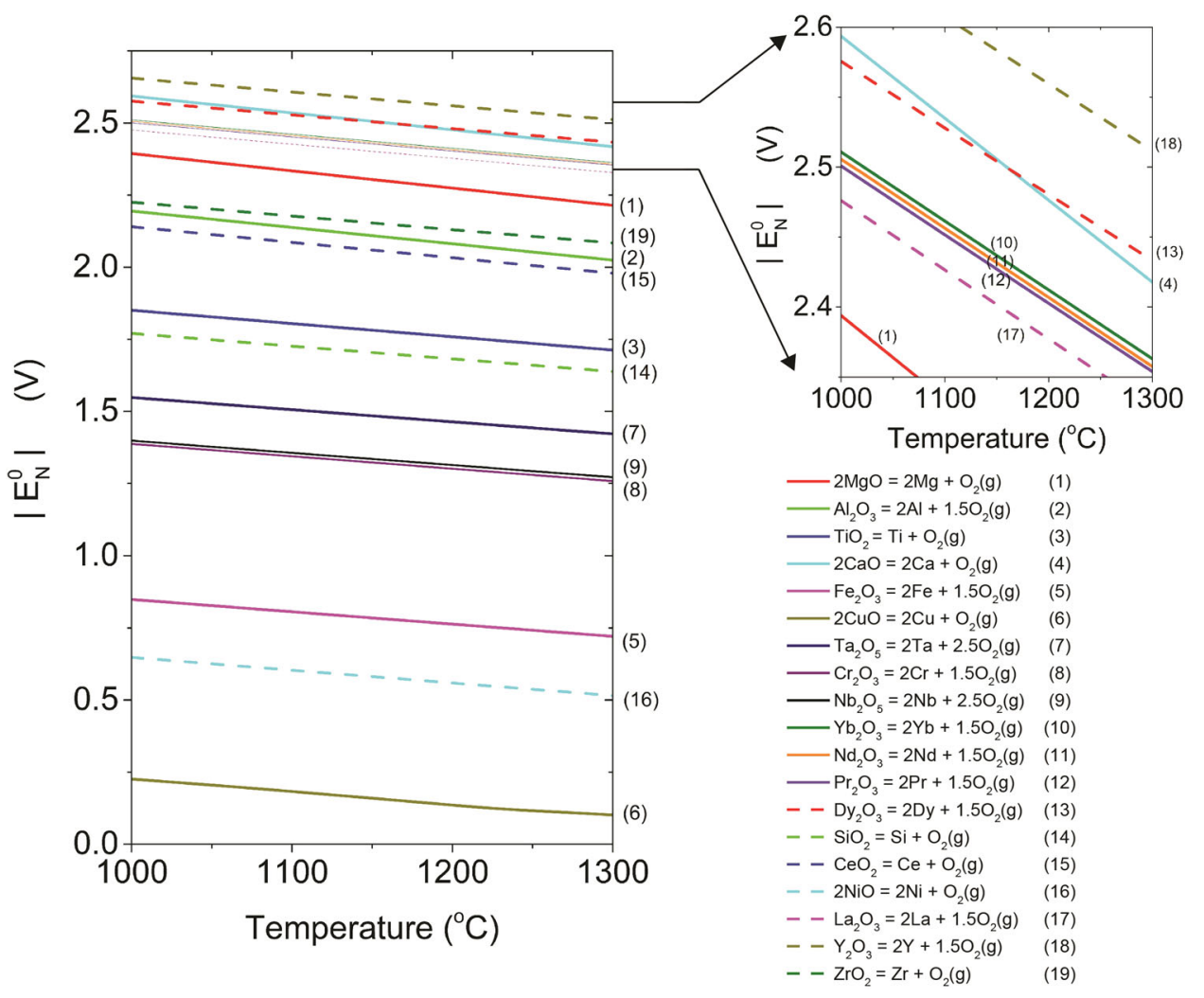

electrolyte must have the right physical and chemical properties.

The cations of the desired metal to be reduced should have a larger electronegativity than the rest of the cations in the flux, so that the desired metal oxide will dissociate before any other oxides present in the flux. In the case of $\mathrm{Mg}$ production by SOM process, the flux composition is typically an eutectic mixture of $\mathrm{MgF}_{2}-\mathrm{CaF}_{2}$ with $10 \% \mathrm{MgO}$ and $2 \% \mathrm{YF}_{3}$. Among all the cations, the electronegativity of magnesium (1.33) is the greatest. When an applied electrical potential across a SOM electrolysis cell exceeds the dissociation potential of $\mathrm{MgO}, \mathrm{Mg}$ is produced at the cathode and $\mathrm{O}_{2}$ evolves at the inert anode. Even if the applied potential exceeds the dissociation of the other metal oxide such as $\mathrm{CaO}$, the reduced $\mathrm{Ca}$ immediately reacts with the adjacent $\mathrm{MgO}$ to form $\mathrm{CaO}$ and $\mathrm{Mg}$.

The flux must have negligible electronic conductivity, or else the Faradaic current efficiency of the process would be low and the applied electrical potential will dissociate the oxygen-ion-conducting zirconia membrane. Also, to improve process yield and reduce extrinsic electronic conductivity, the flux must have low solubility for the metal produced [22, 23]. During SOM electrolysis, experimental techniques have been established in our laboratory to monitor the electronic conductivity in the flux by measuring the electronic transference number [23]. This is done using electrochemical impedance spectroscopy (EIS) and measuring current employing very small potentials less than the dissociation potential of the oxide. Impedance spectroscopy is used to measure the ohmic resistance of the flux. Potentiostatic hold with a very small DC potential (typically less than $0.1 \mathrm{~V}$ ) between two electrodes is used to measure the electronic resistance of the flux. The two resistances are then used to calculate the electronic transference number of the flux. The electronic transference number is monitored during electrolysis to ensure that the flux is mostly ionic so that high current efficiency can be maintained.

The next important requirement is that the SOM must be chemically stable in contact with the flux. The chemical stability, as in similar high-temperature systems, can generally be controlled by matching the optical basicity as well as the yttrium activity between the membrane and the flux. Optical basicity is a critical factor to be considered for the molten salt-YSZ interaction because it reflects the nature of chemical bonding between a Lewis acid-base pair and is quantitatively related to electronic polarizability and electronegativity [53, 54]. Experimental studies show that the YSZ membrane is stable during SOM electrolysis for $\mathrm{Mg}$ production using eutectic $\mathrm{MgF}_{2}-\mathrm{CaF}_{2}$ flux with $10 \mathrm{wt} \%$ dissolved $\mathrm{MgO}$ and $2 \mathrm{wt} \% \mathrm{YF}_{3}$. This is partly because the optical basicity of $\mathrm{MgO}(0.78)$ is relatively close to that of 
$\mathrm{ZrO}_{2}(0.90)$ in the membrane $[53,55]$. However, in the SOM electrolysis for $\mathrm{Al}$ production, $\mathrm{Al}_{2} \mathrm{O}_{3}$ has a smaller optical basicity (0.6), and is expected to corrode the YSZ membrane. The optical basicity mismatch between $\mathrm{Al}_{2} \mathrm{O}_{3}$ and $\mathrm{ZrO}_{2}$ can be compensated by $\mathrm{CaO}$ addition to the flux since $\mathrm{CaO}$ has a greater optical basicity (1.0). Regarding the yttrium activity, a proper amount of $\mathrm{YF}_{3}$ (or $\mathrm{Y}_{2} \mathrm{O}_{3}$ ) needs to be added to the flux to prevent the diffusion of yttria into and out of the YSZ membrane during SOM electrolysis [52, 56, 57]. In other words, the amounts of high-optical basicity oxide (e.g., $\mathrm{CaO}$ ) and $\mathrm{YF}_{3}\left(\right.$ or $\mathrm{Y}_{2} \mathrm{O}_{3}$ ) addition should be tailored to match both the optical basicity and the yttrium activity between the membrane and the flux.

To decrease electrical losses in the system and increase energy efficiency, the flux must have a high ionic conductivity and low viscosity; the former lowers ohmic resistance and the later lowers mass transfer resistance. These two properties of flux are both greatly affected by the degree of polymerization of the flux: the higher the degree of polymerization, higher is the ionic resistivity and the viscosity. Previous work on metallurgical slag suggests that oxide with a lower optical basicity (e.g., $\mathrm{SiO}_{2}, \mathrm{Al}_{2} \mathrm{O}_{3}$ ) serves as network-former (increases the polymerization), whereas oxide with a higher optical basicity (e.g., $\mathrm{MgO}, \mathrm{CaO}$ ) reduces polymerization, and thus increases the flux's ionic conductivity and reduces its viscosity [58]. Additionally, the flux ionic conductivity also depends on the mobility and concentration of the ions. The flux ionic conductivity can be accurately measured by a height-differential technique with coaxial cylindrical electrodes $[59,60]$. For determining the flux viscosity, a typical method is using an inner cylinder rotation technique in a graphite crucible [61, 62].

Lastly, having a low volatility would ensure that the process can be run for a long time without major changes occurring in the composition of the flux. The flux volatility is typically measured using thermogravimetric analysis (TGA) technique [62].

Generally speaking, at the operating temperature, the flux should have low electronic transference number $(<0.1)$, low solubility for the metal produced $(<0.1 \mathrm{wt} \%)$, adequate solubility for the metal oxide ( $>3 \mathrm{wt} \%$ ), adequate ionic conductivity $(>10 \mathrm{~S} / \mathrm{m})$, low viscosity $(<0.1 \mathrm{~Pa} \mathrm{~s})$, low volatility $\left(<10^{-6} \mathrm{~g} \mathrm{~cm}^{-2} \mathrm{~s}^{-1}\right)$, and be chemically stable in contact with the membrane and the cathode for long operating life.

\section{Applications of SOM Process}

In a real sense, SOM electrolysis process provides a universal platform for the production of various metals and alloys. When an applied electrical potential across a SOM electrolysis cell exceeds the dissociation potential of a metal oxide, metal is produced at the cathode and $\mathrm{O}_{2}$ evolves at the anode following the direct electrochemical reaction: $\mathrm{MeO}_{x}=\mathrm{Me}+x / 2 \quad \mathrm{O}_{2}(\mathrm{~g})$. The dissociation potential of $\mathrm{MeO}_{x}$ is equal to the absolute value of the Nernst potential $\left(E_{\mathrm{N}}\right)$ for the direct electrochemical reaction. $E_{\mathrm{N}}$ can be expressed as follows:

$E_{\mathrm{N}}=E_{\mathrm{N}}^{0}+\frac{R T}{x F} \ln \left[\frac{a_{\mathrm{MeO}_{x}(\mathrm{flux})}}{a_{\mathrm{Me}} \cdot\left(a_{\mathrm{O}_{2}(\mathrm{~g})}\right)^{x / 2}}\right]$,

where $E_{\mathrm{N}}^{0}$ is the standard Nernst potential for $\mathrm{MeO}_{x}$ dissociation, $R$ is the gas constant $(8.31 \mathrm{~J} /(\mathrm{mol} \mathrm{K})), T$ is the operating temperature, $F$ is the Faraday constant $(96,485 \mathrm{C} / \mathrm{mol})$, $a_{\mathrm{MeO}_{x} \text { (flux) }}, a_{\mathrm{Me}}$, and $a_{\mathrm{O}_{2}(\mathrm{~g})}$ are the activities of the metal oxide dissolved in flux, the metal produced at cathode, and the $\mathrm{O}_{2}(\mathrm{~g})$ evolved at anode, respectively. During SOM experiment, the absolute value of $E_{\mathrm{N}}$ is identified at the deflection point of the current-potential curve obtained from a linear potential sweep between the anode and cathode. The values of $E_{\mathrm{N}}$ and $E_{\mathrm{N}}^{0}$ are usually close. To provide a comprehensive reference, the absolute values of $E_{\mathrm{N}}^{0}$ for the dissociation of various metal oxides at the operating temperature range of $1000-1300{ }^{\circ} \mathrm{C}$ are calculated using HSC Chemistry 5.11 database [63] and are summarized in Fig. 4.

In the following subsections, we will give specific examples for the production of $\mathrm{Mg}, \mathrm{Al}, \mathrm{Si}$, rare earth metals such as $\mathrm{Yb}$, and $\mathrm{Ta}$.

\section{Magnesium}

Magnesium is a leading candidate to replace steel and aluminum in automobiles due to its superior strength-toweight ratio $[64,65]$. The SOM electrolysis technology for $\mathrm{Mg}$ production promises to eliminate GHG emissions, decrease plant footprint and energy consumption, and boost production rates. In addition, an independent study has shown the environmental, energy and cost benefits of the SOM process compared to the state-of-the-art processes, such as the Pidgeon process and the western electrolytic process, for magnesium production [7].

Over the past decade, significant progress has been made on the SOM process for Mg production. In 2005, Krishnan et al. demonstrated successful lab-scale production of $\mathrm{Mg}$ by the SOM process [19]. Later, Gratz et al. solved the yttrium depletion problem from the YSZ membrane by adding $2 \mathrm{wt} \% \mathrm{YF}_{3}$ to the flux consisting of a eutectic mixture of $\mathrm{MgF}_{2}-\mathrm{CaF}_{2}$ and $10 \mathrm{wt} \% \mathrm{MgO}$ [56]. Afterward, Guan et al. first introduced the use of LSM-Inconel inert anode current collector for pure oxygen evolution at the anode with $\mathrm{Mg}$ production at the cathode [21].

Figure 5a shows a schematic of the SOM process for $\mathrm{Mg}$ and $\mathrm{O}_{2}$ production. Pure $\mathrm{O}_{2}$ evolved at a liquid silver anode 
encased inside a YSZ tube. Meanwhile, $\mathrm{Mg}$ was produced as vapor at the stainless steel bubbling tube cathode. $\mathrm{Ar} / \mathrm{H}_{2}$ mixture was passed through the stainless steel bubbling tube and served as a carrier gas to transport the $\mathrm{Mg}$ vapor out of the molten flux. The Mg vapor was collected in a separate condenser with a temperature lower than the melting point of $\mathrm{Mg}$ $(923 \mathrm{~K})$. The results of a linear potential sweep conducted between the inert anode current collector and the stirring tube cathode are shown in Fig. 5b. The dissociation potential of $\mathrm{MgO}(2.1 \mathrm{~V})$ identified at the deflection point of the currentvoltage curve is close to the standard Nernst potential $(2.31 \mathrm{~V})$ for the reaction $\mathrm{MgO}=\mathrm{Mg}(\mathrm{g})+\mathrm{O}_{2}(\mathrm{~g})$ at $1423 \mathrm{~K}$. The explanation for the reduced potential was that the Ar bubbling through the cathode tube decreased the activity of magnesium vapor produced at the cathode. Figure $5 \mathrm{c}$ shows the $\mathrm{Mg}$ collected after a SOM electrolysis experiment. Figure 5d shows the EDS (energy-dispersive X-ray spectroscopy) of the $\mathrm{Mg}$ collected and confirms the high purity of $\mathrm{Mg}$ [21].

\section{Aluminum}

Ending up in everything from soda cans to bicycles and to baseball bats, aluminum is the world's second most commonly used metal after iron. While the global market for aluminum is estimated at $\$ 100$ billion and growing, its production is energy-intensive, accompanied by toxic emissions of perflurocarbons (PFCs), poly aromatic hydrocarbons (PAHs), oxides of carbon $\left(\mathrm{CO}_{2}\right)$, and sulfur $\left(\mathrm{SO}_{2}\right)$. These pollutants are major sources of GHG emissions linked to global climate change, smog, and acid rain. Conventional $\mathrm{Al}$ production employs carbon anodes and consumes $13-15 \mathrm{~kW}$ hours of electrical energy per kilogram of aluminum and produces $7-10 \mathrm{~kg}$ of $\mathrm{CO}_{2}$ and smaller amounts of other GHGs such as perfluorocarbons $\left(\mathrm{CF}_{4}\right.$ and $\left.\mathrm{C}_{2} \mathrm{~F}_{6}\right)$ which have 1000-10,000 times the global warming potential (GWP) of $\mathrm{CO}_{2}$. In our SOM process for aluminum production carbon anodes are replaced by the LSM-Inconel inert anode and current collectors enclosed within oxygen-ion-conducting SOM tubes that are made of stabilized zirconia. By removing the carbon anode and its manufacture we would eliminate most of the sources for the air pollutants.

The feasibility for aluminum production was successfully demonstrated using a laboratory scale SOM electrolysis cell (Fig. 6) with a LSM-Inconel inert anode current collector at $1473 \mathrm{~K}$. The cathode was made of $\mathrm{TiB}_{2}$, an inert electrical conductor that does not alloy with Al. The $\mathrm{TiB}_{2}$ used in the experiment was made using electric discharge machining. The bottom end of the $\mathrm{TiB}_{2}$ bar was immersed in the flux for $\mathrm{Al}$ deposition. A boron nitride (BN) tube hung by a SS (stainless steel) pin surrounded the $\mathrm{TiB}_{2}$ cathode and thus enclosed the liquid aluminum product that floated over the molten salt (a eutectic mixture of $\mathrm{MgF}_{2}-\mathrm{CaF}_{2}$ with $6 \mathrm{wt} \% \mathrm{CaO}$ and $3 \mathrm{wt} \% \mathrm{Al}_{2} \mathrm{O}_{3}$ ). The top end of the $\mathrm{TiB}_{2}$ was connected using a hook structure to a SS crucible containing liquid Ag which provided the connection between the $\mathrm{TiB}_{2}$ cathode and the SS rod current collector. This cathode design has a negligibly small ohmic resistance and a convenient way to collect the floating liquid $\mathrm{Al}$ deposits. Forming gas $\left(98 \% \mathrm{Ar}-2 \% \mathrm{H}_{2}\right)$ passed through a SS stirring tube which stirred the flux, and improved the mass transfer kinetics.
Fig. 5 a Schematic of the SOM electrolysis cell for $\mathrm{Mg}$ and $\mathrm{O}_{2}$ production at $1373-1573 \mathrm{~K}$ (1100-1300 $\left.{ }^{\circ} \mathrm{C}\right)$. b Currentvoltage relationship obtained from linear potential sweep performed between the inert anode current collector and the bubbling tube cathode. $\mathbf{c ~} \mathrm{Mg}$ collected after a SOM electrolysis experiment. d EDS analysis shows the high purity of the collected $\mathrm{Mg}(\mathbf{b}-\mathbf{d}$ are reproduced with permission) [21]
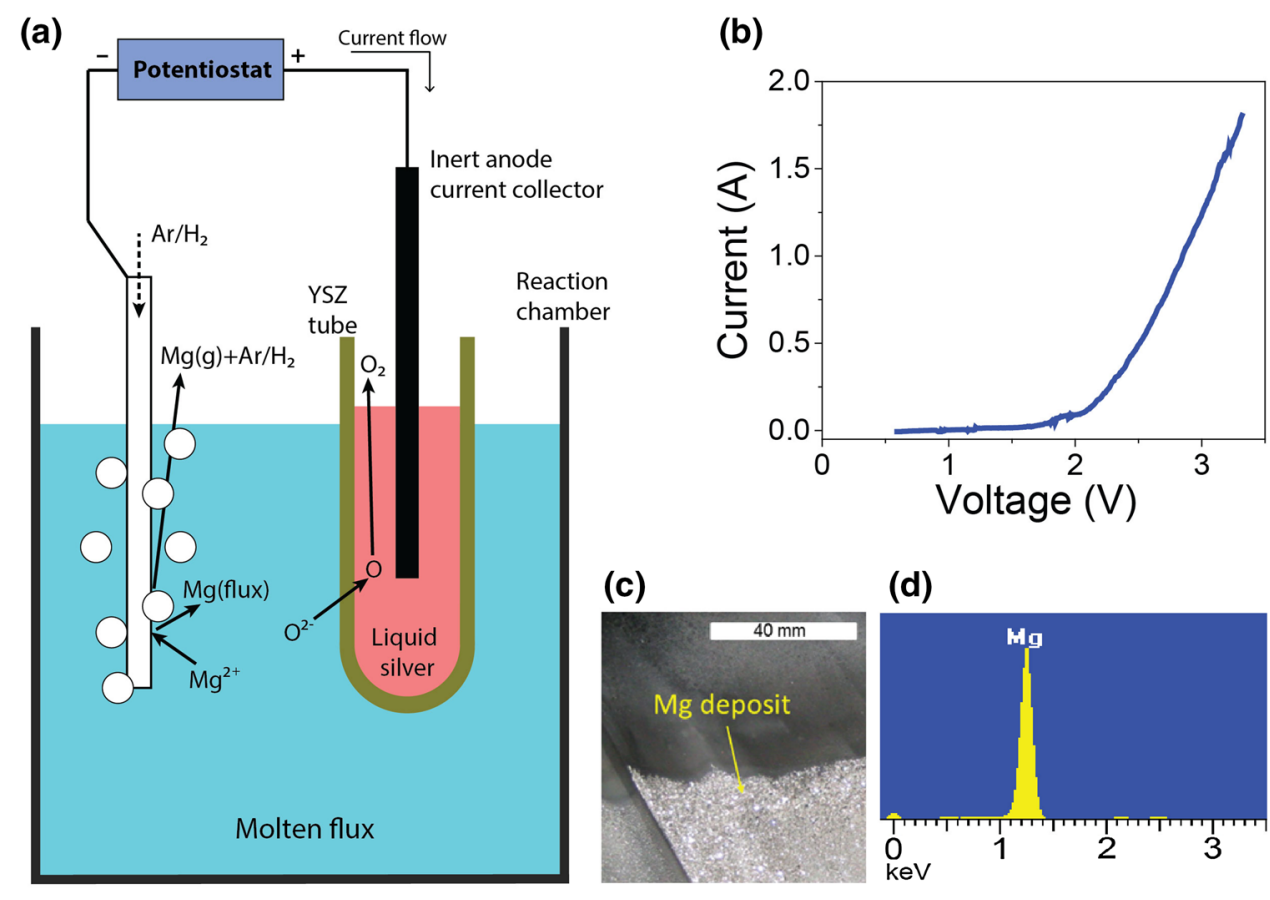

(c)

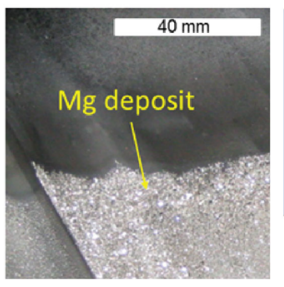

(d)

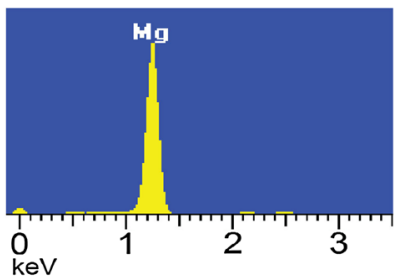


(a)

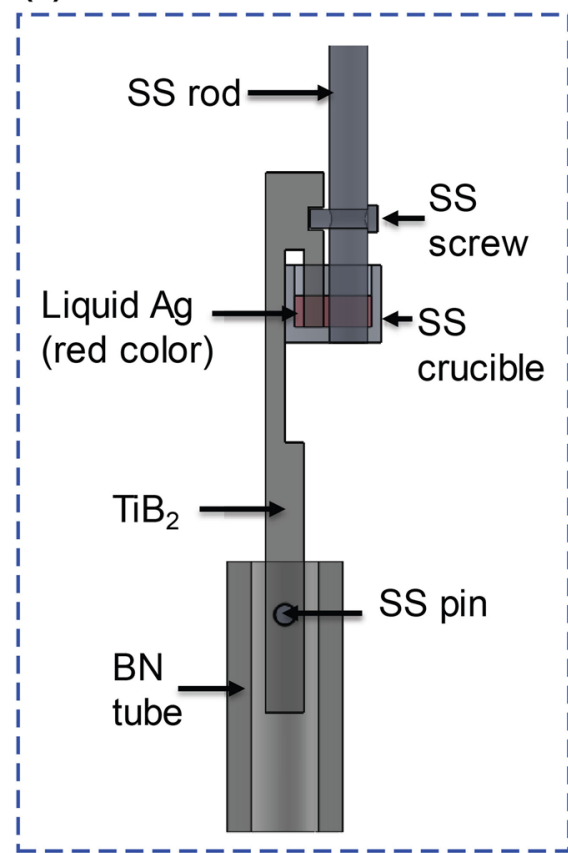

Fig. 6 a Schematic of SOM electrolysis cell for $\mathrm{Al}$ and $\mathrm{O}_{2}$ production at $1473 \mathrm{~K}\left(1200{ }^{\circ} \mathrm{C}\right)$. b Current-voltage characteristic obtained from linear potential sweep performed between the inert anode current collector and the $\mathrm{TiB}_{2}$ cathode. $\mathbf{c}$ SEM image of a piece (b)

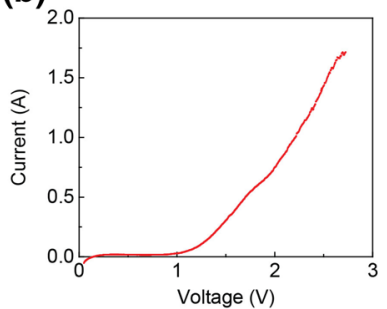

(c)

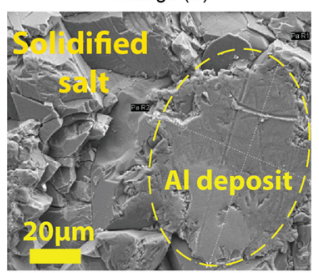

(d)

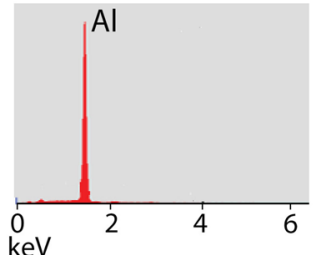

The results of a linear potential sweep conducted between the inert anode current collector and the $\mathrm{TiB}_{2}$ cathode is shown in Fig. 6b. The dissociation potential of $\mathrm{Al}_{2} \mathrm{O}_{3}$ was identified to be approximately $2.1 \mathrm{~V}$. The presence of small leakage current prior to the dissociation potential of $\mathrm{Al}_{2} \mathrm{O}_{3}$ was likely due to impurity oxides in the molten salt or carbon monoxide inside the reaction chamber. When the applied potential exceeds the dissociation potential of alumina, liquid $\mathrm{Al}$ is produced at the cathode and pure $\mathrm{O}_{2}$ is produced at the anode according to the electrochemical reaction: $\mathrm{Al}_{2} \mathrm{O}_{3} \rightarrow 2 \mathrm{Al}$ (cathode) $+3 / 2 \mathrm{O}_{2}$ (anode). Electrolysis at $2.75 \mathrm{~V}$ was performed for over $20 \mathrm{~h}$. After SOM electrolysis, the setup was sectioned, and aluminum was found inside the boron nitride tube (see Fig. 6c). Energydispersive X-ray spectroscopy (EDS) analysis showed that the aluminum produced has a purity of $99 \%$ (Fig. 6d). This proof-of-concept experiment not only demonstrates the feasibility but also provides insights into characteristics of a large-scale SOM electrolysis cell for $\mathrm{Al}$ production.

\section{Solar-Grade Silicon (SoG-Si)}

Currently, over $90 \%$ of the silicon production starts with carbothermic reduction of silica $\left(\mathrm{SiO}_{2}\right)$ to metallurgicalgrade (MG) Si followed by its purification that involves of $\mathrm{Al}$ deposit (circled by a dashed ellipse) surrounded by solidified salt near the $\mathrm{TiB}_{2}$ cathode after a SOM electrolysis experiment. d EDS analysis shows the high purity of the $\mathrm{Al}$ deposit

chlorination, distillation, and chemical vapor deposition on a hot wire substrate. This process, also known as the Siemens process [9], involves multiple steps, is extremely energy-intensive, has low capital utilization, and produces much higher product purity (10-11 nines) than needed for solar cells (6 nines). Compared with the Siemens process, the SOM-based electrolytic process is an innovative process having several advantages: inexpensive inputs requiring little to no pre-treatment; no carbothermic reduction, which emits $10 \mathrm{~kg}$ of $\mathrm{CO}_{2}$ per $\mathrm{kg}$ Si product and whose contaminants typically reduce purity from $99.6 \%$ $\mathrm{SiO}_{2}$ in sand to $97-98 \%$ in metallurgical-grade (MG) Si; no carbon or chlorine anywhere in the process; and no anode effects resulting in perfluoro and/or perchloro carbons.

Feasibility studies of the SOM process for silica electrolysis with liquid tin cathode and LSM-Inconel inert anode current collector was performed at $1300{ }^{\circ} \mathrm{C}$. Schematic of the electrolysis cell is shown in Fig. 7a. The reduced silicon dissolved in a liquid tin cathode and crystalized upon cooling to produce high-purity silicon crystals. Tungsten (W) rod served as a cathode current collector. A BN sleeve separated the $\mathrm{W}$ rod from the molten flux to prevent $\mathrm{Si}$ deposition on the $\mathrm{W}$ rod. The molten flux was a eutectic mixture of $\mathrm{BaF}_{2}-\mathrm{MgF}_{2}$ with $2 \mathrm{wt} \% \mathrm{SiO}_{2}$ and 
$15 \mathrm{wt} \% \mathrm{YF}_{3}$. These selected amounts of $\mathrm{SiO}_{2}$ and $\mathrm{YF}_{3}$ were determined from the stability tests performed on the YSZ membrane [52]. The results of linear potential sweep conducted between the $\mathrm{W}$ cathode current collector and the inert anode current collector are shown in Fig. 7b. The dissociation potential of silica was identified to be approximately $1.6 \mathrm{~V}$, close to the standard Nernst potential $(1.638 \mathrm{~V})$ for the reaction $\mathrm{SiO}_{2}=\mathrm{Si}+\mathrm{O}_{2}(\mathrm{~g})$ at $1300{ }^{\circ} \mathrm{C}$. Electrolysis at $2.25 \mathrm{~V}$ was performed for $4.5 \mathrm{~h}$ to reduce the silicon at the cathode: $\mathrm{Si}^{4+}+4 \mathrm{e} \rightarrow \mathrm{Si}$ (in liquid tin). The quantity of liquid tin cathode was sufficient to dissolve all the silicon reduced. Silicon crystals precipitated out as the liquid $\mathrm{Si}-\mathrm{Sn}$ alloy was slowly cooled after electrolysis. Figure 7c shows the SEM image of a Si crystal embedded in solidified tin. The silicon crystals were then extracted from tin by wet-chemical etching with hydrochloric acid at room temperature. EDS analysis confirmed that they were high-purity silicon crystals (see Fig. 7d).

\section{Rare Earth Metals}

Demand for the rare earth metals has grown dramatically over the past five decades. For example, the strongest rare earth magnets are made from $\mathrm{Nd}_{2} \mathrm{Fe}_{14} \mathrm{~B}$, with some substitution of other rare earths such as dysprosium (Dy) for neodymium $(\mathrm{Nd})$ [43]. These magnets are essential for electric motors and generators used in wind turbines and electric vehicles because they provide the highest powerto-weight ratios. Green production of rare earth metals is critically important for continued growth of clean energy technologies. Today's manufacturing of rare earth metals for magnets is capital- and energy-intensive, and also generates large amounts of pollutants. The manufacturing process involves a disposable graphite pot that can only last a couple of week's production which limits the continuous production of the metal and introduces carbon impurity into the product. Furthermore, in today's rare earth production furnaces, PFC emission occurs because of the use of carbon anodes and fluoride salts. In contrast, SOM technology does not use any carbon in contact with the metal or the salt. The crucible does not react, resulting in much longer lifetime, and higher furnace utilization, leading to lower capital cost. The use of oxygen-ion-conducting membrane as part of the anode also eliminates PFC production, and results in a high-purity value-added oxygen byproduct. The process can make $100 \mathrm{~kg}$ or larger batches, and uses fewer labor hours, resulting in lower cost. It was reported that INFINIUM Inc. has recently established its SOM-based rare earth metals production to supply Nd and DyFe alloy to the magnet industry [66].

The feasibility for rare earth metals production has been successfully demonstrated using a laboratory scale SOM electrolysis cell. For instance, previous work has reported SOM electrolysis for $\mathrm{Yb}$ production [33]. Figure 8a shows
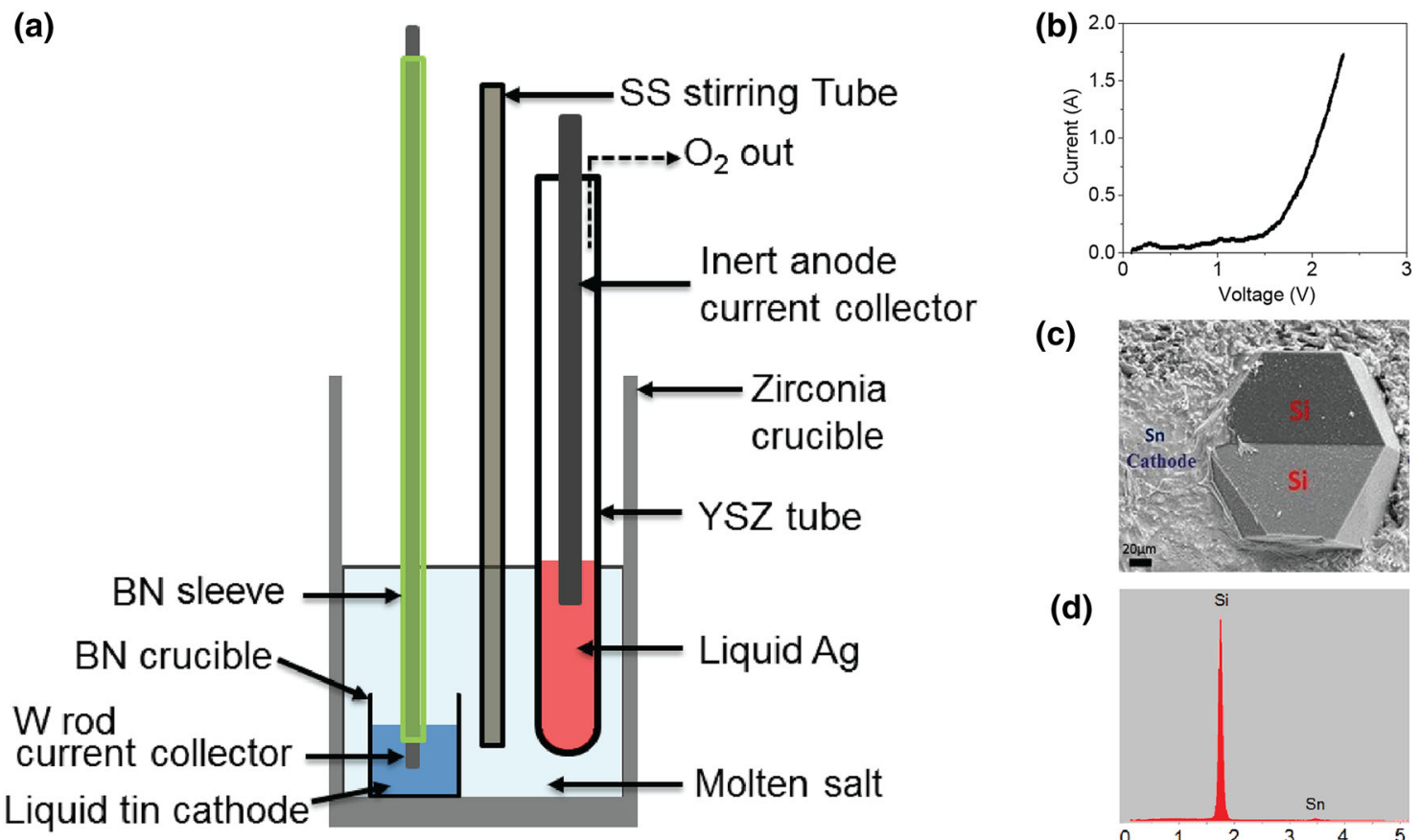

(c)

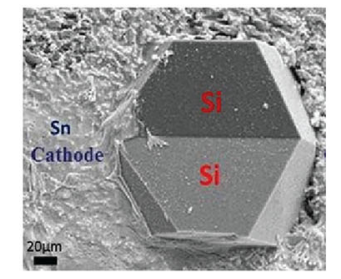

(d)

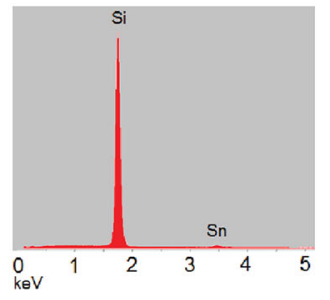

Fig. 7 a Schematic of SOM electrolysis cell for $\mathrm{Si}$ and $\mathrm{O}_{2}$ production at $1573 \mathrm{~K}\left(1300{ }^{\circ} \mathrm{C}\right)$; b current-voltage relationship of the SOM electrolysis cell. The dissociation potential of $\mathrm{SiO}_{2}$ was identified to be approximately $1.638 \mathrm{~V}$; c SEM image of a Si crystal embedded in the solidified tin cathode; $\mathbf{d}$ EDS result confirmed the presence of high-purity Si crystals 
(a)

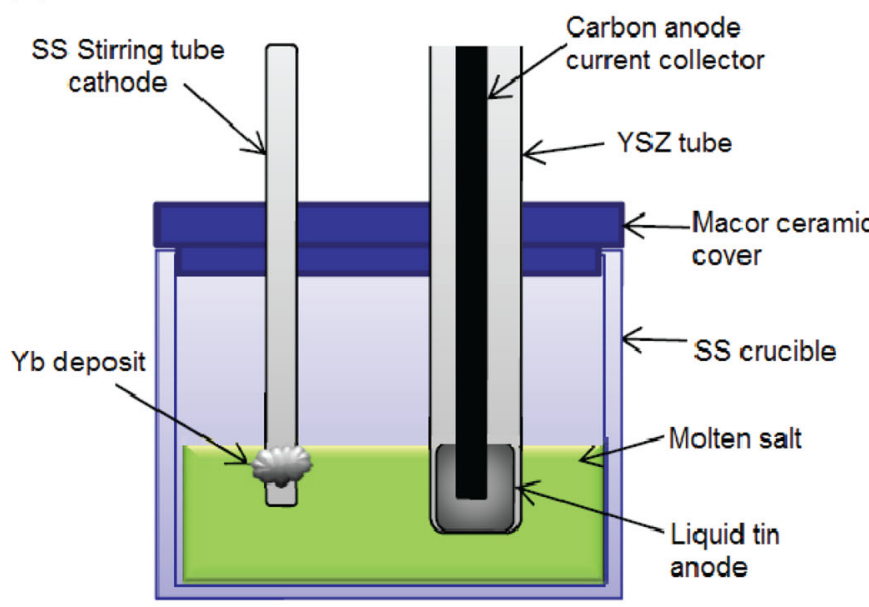

(b)

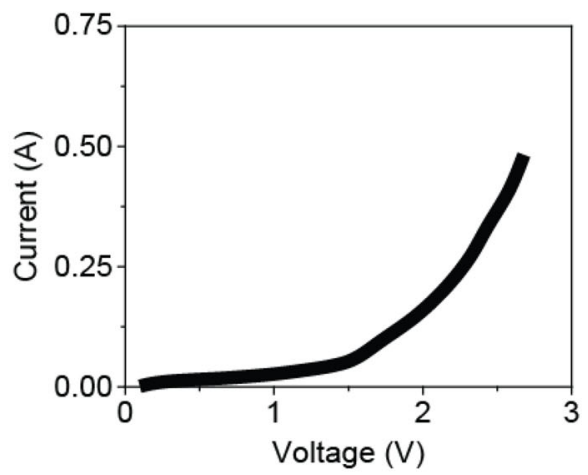

(c)

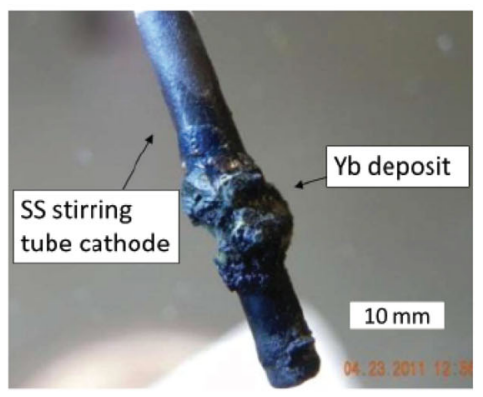

(f)

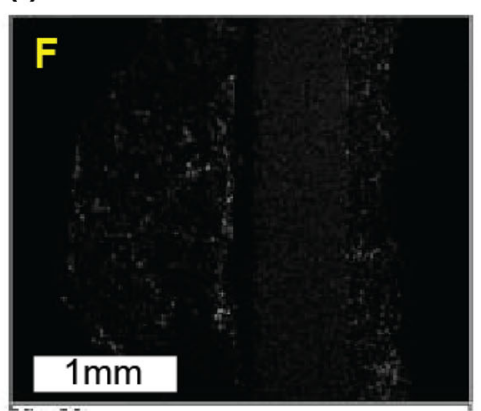

(d)

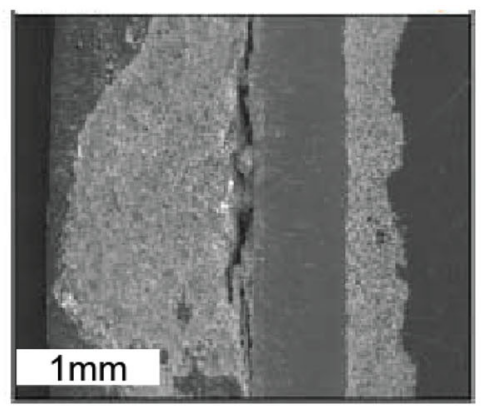

(e)

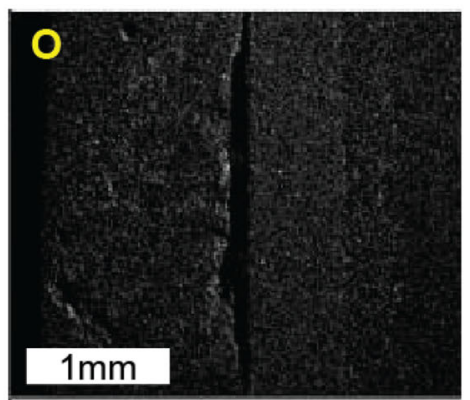

(g)

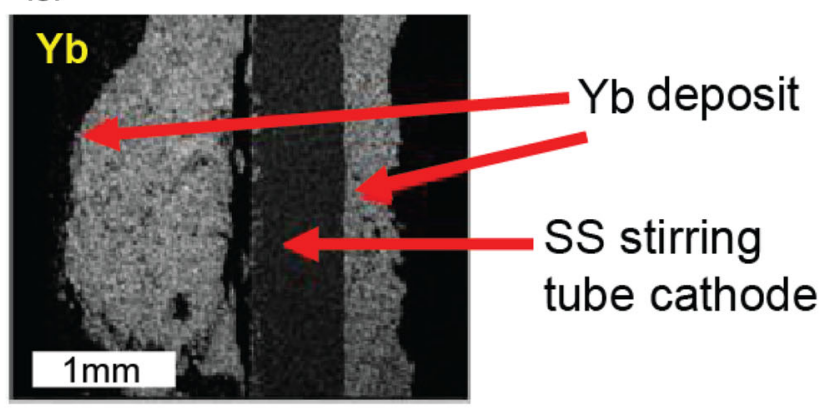

Fig. 8 a Schematic of SOM electrolysis cell for $\mathrm{Yb}$ production at $1073 \mathrm{~K}\left(80{ }^{\circ} \mathrm{C}\right)$. A carbon anode current collector was used rather than an inert anode current collector; $\mathbf{b}$ current-voltage relationship of the SOM electrolysis cell. The dissociation potential of $\mathrm{Yb}_{2} \mathrm{O}_{3}$ for the reaction $\mathrm{Yb}_{2} \mathrm{O}_{3}+3 \mathrm{C}=2 \mathrm{Yb}+3 \mathrm{CO}(\mathrm{g})$ was identified to be around $1.5 \mathrm{~V}$. c A photograph of $\mathrm{Yb}$ metal deposit on the stainless steel

the schematic of the SOM electrolysis cell. This experiment was performed at $1073 \mathrm{~K}$ using a low-melting point eutectic mixture of $\mathrm{LiF}-\mathrm{YbF}_{2}$ molten flux with $11 \mathrm{wt} \% \mathrm{Yb}_{2} \mathrm{O}_{3}$. But here, instead of an inert anode, a carbon rod was used as the anode current collector and a stainless steel gas stirring tube was used as the cathode for $\mathrm{Yb}$ deposition. A reducing gas consisting of $5 \% \mathrm{H}_{2}$ was passed through the stirring tube to purge the chamber and stir the molten salt. Figure $8 \mathrm{~b}$ shows cathode. d SEM image of the cross section of the cathode tube with deposit. e-g Show the EDS X-ray mapping of the elements oxygen $(\mathrm{O})$, fluorine $(\mathrm{F})$, and ytterbium $(\mathrm{Yb})$, respectively, in the same area shown in (d). Reproduced with permission from Jiang et al. [33]. Copyright 2012, The Electrochemical Society

the current-voltage relationship obtained from a linear potential sweep conducted between the carbon anode current collector and the stirring tube cathode. The dissociation potential of $\mathrm{Yb}_{2} \mathrm{O}_{3}$ was identified to be approximately $1.5 \mathrm{~V}$, close to the standard Nernst potential $(1.54 \mathrm{~V})$ for the reaction $\mathrm{Yb}_{2} \mathrm{O}_{3}+\mathrm{C}=\mathrm{Yb}+\mathrm{CO}(\mathrm{g})$ at $1073 \mathrm{~K}$. Electrolysis at $2.5 \mathrm{~V}$ was performed for $4.5 \mathrm{~h}$. The $\mathrm{Yb}$ deposit on the stainless steel cathode after SOM electrolysis is shown in 
Fig. 8c. The deposit on the cathode was sectioned and analyzed using SEM as shown in Fig. 8d. EDS X-ray mapping was used to verify the composition of the deposit. Figure $8 \mathrm{e}-\mathrm{g}$ shows the distribution of oxygen $(\mathrm{O})$, fluorine $(\mathrm{F})$, and ytterbium $(\mathrm{Yb})$, respectively. The elements $\mathrm{O}$ and $\mathrm{F}$ showed a uniformly weak signal. However, the mapping for $\mathrm{Yb}$ showed strong signal confirming the presence of $\mathrm{Yb}$ in the deposit on the stainless steel cathode.

\section{Reduction of Non-soluble Oxides}

The SOM process described thus far typically requires a molten salt with an adequate metal oxide solubility to reduce mass transfer resistance and achieve high current densities. However, SOM process can also be employed to dissociate metal oxides that have low or negligible solubility in the molten salt. This is done by incorporating a similar cathode design to the FFC Cambridge process [67]. Instead of dissolving the desired metal oxide, it can be sintered into a porous cathode pellet and immersed in a fluoride or chloride (e.g., $\mathrm{CaCl}_{2}$ ) flux together with a SOM anode. This SOM cell design reduces the restrictions for flux selection and provides a pathway for producing refractory metals and high-melting point rare earth metals, especially, at a lower operating temperature (between 1273 and $1573 \mathrm{~K}$ ).

Krishnan et al. first demonstrated the technical viability of the SOM technology with carbon anode current collector to produce $\mathrm{Ta}$ metal directly from sintered $\mathrm{Ta}_{2} \mathrm{O}_{5}$ pellets [20]. Figure 9a shows the schematic of the SOM electrolysis cell for Ta production with a $\mathrm{Ta}_{2} \mathrm{O}_{5}$ pellet as cathode and $\mathrm{MgF}_{2}-$ $\mathrm{CaF}_{2}$ molten salt as electrolyte at $1423 \mathrm{~K}$. The oxides of Ta are electronically conductive and therefore serve well as the cathode. The current-voltage relationship obtained from a linear potential sweep is shown in Fig. 9b. The dissociation potential of $\mathrm{Ta}_{2} \mathrm{O}_{5}$ was identified to be less than $0.1 \mathrm{~V}$, close to the standard Nernst potential $(0.12 \mathrm{~V})$ for the reaction
$\mathrm{Ta}_{2} \mathrm{O}_{5}+\mathrm{C}=\mathrm{Ta}+\mathrm{CO}(\mathrm{g})$ at $1423 \mathrm{~K}$. A diffusion-limited behavior observed in the current range from 0.2 to $0.6 \mathrm{~A}$ was attributed to the relatively slow oxygen transport in the $\mathrm{Ta}_{2} \mathrm{O}_{5}$ pellet. This diffusion-limited behavior can be mitigated by optimizing the porosity of the pellet and thereby allowing the flux to penetrate the pellet. The increase in current observed above $0.8 \mathrm{~V}$ can be attributed to the dissociation of $\mathrm{MgO}$ by $\mathrm{C}$ (standard Nernst potential for $\mathrm{MgO}+\mathrm{C}=\mathrm{Mg}(\mathrm{g})+\mathrm{CO}(\mathrm{g})$ is $0.8 \mathrm{~V})$; the $\mathrm{MgO}$ activity in the flux arises due to the $\mathrm{Mg}^{2+}$ ions (from $\mathrm{MgF}_{2}$ ) and the $\mathrm{O}^{2-}$ ions (from the oxide pellet). Figure $9 \mathrm{c}$ shows the SEM image of the reduced Ta metal in the pellet after electrolysis. A wavelength-dispersive X-ray spectroscopy (WDS) analysis of the composition of the Ta reduced in another similar experiment confirmed the very high purity $(99.878 \%)$ of the Ta deposit.

Afterwards, Zhao et al. reported the direct electrochemical preparation of $\mathrm{CeNi}_{5}$ and $\mathrm{La}_{x} \mathrm{Ce}_{1-x} \mathrm{Ni}_{5}$ hydrogen storage alloys from a sintered $\mathrm{NiO}-\mathrm{CeO}_{2}$ pellet and a sintered $\mathrm{NiO}-\mathrm{CeO}_{2}-\mathrm{La}_{2} \mathrm{O}_{3}$ pellet, respectively, immersed in molten $\mathrm{CaCl}_{2}$ at $1273 \mathrm{~K}$ by SOM process [35]. This SOM cell design not only has all the advantages of the FFC Cambridge process but also allows the application of a high applied potential $(3.5 \mathrm{~V})$ without dissociating the $\mathrm{CaCl}_{2}$ salt, which is a great advantage in terms of getting higher current densities. Similar SOM cell design has also been used to produce various refractory metals and alloys including $\mathrm{Nb}, \mathrm{Cr}$, Ti, Ti-Fe alloy, Ti-Si alloy [36-39].

\section{Challenges and Future Work}

The SOM electrolysis process is an energy-effective and environmentally benign route for one-step oxide to metal conversion. Further research and development of commercially viable SOM electrolysis process is critical in
Fig. 9 a Schematic of the SOM electrolysis cell for Ta production with oxide pellet as cathode. 1-carbon anode current collector, 2-alumina separator, 3-stainless steel cap, 4-YSZ tube, 5-molten salt, 6-liquid copper anode, 7-stainless steel reactor, 8-cathode electrical lead, 9-tantalum oxide pellet. b current-voltage relationship for a SOM experiment. c SEM image of the reduced Ta metal surrounded by the unreduced tantalum oxide in the pellet. Reproduced with permission from Krishnan et al. [20]. Copyright 2005, Wiley (a)

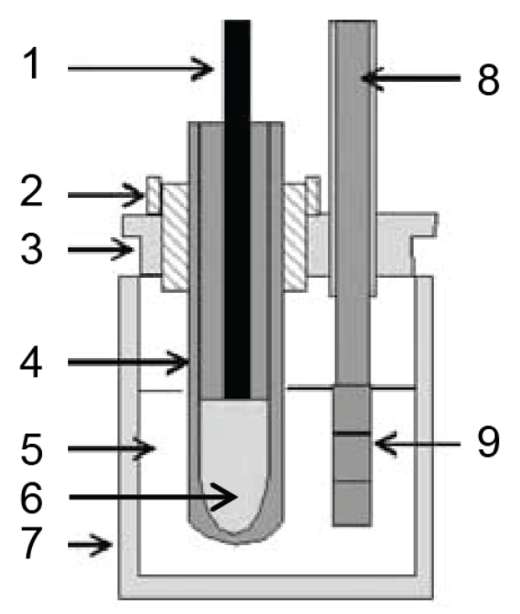

(b)

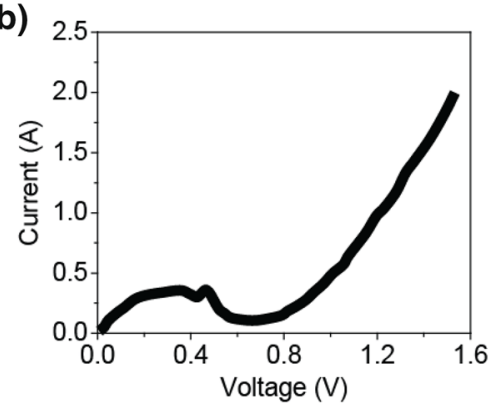

(c)

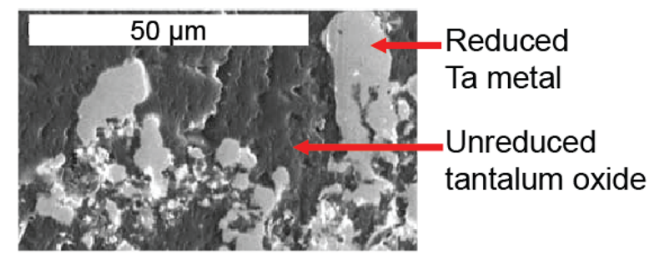


order for it to compete with the state-of-the-art metal production processes. This presents challenges particularly with respect to durability and materials compatibility within the SOM electrolysis cells at the high operating temperatures. It also offers exciting opportunities to explore new molten flux chemistries for the stability of YSZ membrane and the purity of the metal products.

The YSZ membrane is typically the life-limiting component within a SOM electrolysis cell for long-term operation, which arises from the complex interaction between the molten flux and the YSZ membrane. Although each desired metal product corresponds to a different molten flux mixture, the yttrium activity in the molten flux electrolyte has been identified as a key parameter and engineered for the chemical (i.e., preventing yttrium depletion) and crystalline structural (i.e., maintaining cubic phase and thus mitigating pore formation) stability of YSZ membrane [52, 56, 57, 68, 69]. Optical basicity of the flux is another critical factor as aforementioned in "Flux Electrolyte" Section. Our work on aluminum production has shown that adding a high-optical basicity oxide $(\mathrm{CaO})$ to the flux significantly improves the stability of the YSZ membrane. Gao et al. have also recently reported a correlation between the optical basicity of the molten salts and the pore formation within YSZ membrane [70]. To completely understand the interaction between each molten flux mixture and the YSZ membrane especially in electrolysis mode, it still requires more detailed investigations from both experimental and theoretical perspectives in the future.

The purity of the metal products can be controlled by optimizing the molten flux composition. For example, if a metal product of high purity is desired, the electronegativity of the desired metal atom must be much larger than that of the other metal atoms present in the flux in the form of cations. The applied electrical potential can be greater than the dissociation potential of the desired metal oxide, but smaller than that of the other metal oxides present in the flux. If an alloy is preferred, the applied electrical potential can be greater than the dissociation potentials of all the desired metal oxides. The high-purity metal product can also be obtained by improving $\mathrm{SOM}$ cell design. For example, high-purity $\mathrm{Mg}$ is collected by evaporating the $\mathrm{Mg}$ product followed by condensing in a separate chamber at a lower temperature [19].

Design of optimum SOM electrolysis cells with small electrical resistances will be of importance in the future work. For example, the thickness and the porosity of the YSZ directly affect the ohmic resistance of the YSZ membrane. Also, increasing the electrocatalytic activities of the electrodes for the charge transfer reactions involved can reduce the charge transfer resistances. A recent study on an equivalent DC circuit modeling of the SOM electrolysis process provides a generic guideline for lowering rate-limiting resistive elements and designing optimum SOM electrolysis cells [71].

\section{Conclusions}

Electrolysis based on oxygen-ion-conducting SOM, inert anode, and inert current collector is an innovative technology that allows energy-efficient and environmentally friendly low cost production of metals from their oxides dissolved in molten halide flux. The SOM electrolytic process has been successfully demonstrated in our laboratory by producing several technologically important metals from their respective oxides dissolved in specific molten fluoride flux systems. Generic guidelines are provided to engineer the molten halide flux and cathode for a particular metal's production. It is a zero-carbon-emission process that produces the desired metal and pure oxygen gas as a value-added byproduct. It is a universal metals production technology that could transform the future of the energy-intensive metals industry.

Other variations of the SOM technology that employ fueled anodes to lower the dissociation potential $\left(\mathrm{C}, \mathrm{CH}_{4}(\mathrm{~g})\right.$, $\mathrm{H}_{2}(\mathrm{~g})$, etc.) and sintered oxide cathode pellets (for oxides not soluble in flux) are also described with examples.

Acknowledgments The authors would like to thank Dr. Adam C. Powell IV for helpful discussion. The authors would also like to acknowledge Dr. Peter Zink, Dr. Eric Gratz, Mr. Alex Roan, Mr. Jarrod Milshtein, Dr. Jiapeng Xu, and Mr. Brian Lo for their contributions to the SOM projects in our group at various times. The material is based on work supported by the Department of Energy (DE-FC36-14GO14011; DE-EE0003454; and DE-EE0005547) and the National Science Foundation (DMI-9424069; DMI-0457381; CBET-1210442; and DMR-08-19762).

\section{References}

1. U.S. Environmental Protection Agency (2015) Greenhouse gas (GHG) inventory in the United States in 2015, Chapter 4, industrial processes and product use. [Online]. http://www.epa. gov/climatechange/ghgemissions/usinventoryreport.html

2. International Energy Agency (2010) Energy technology perspective. [Online]. http://www.iea.org/publications/freepublications/ publication/etp2010.pdf

3. Ehrenberger S (2013) Life cycle assessment of magnesium components in vehicle. International Magnesium Association, Wauconda, IL

4. Friedrich H, Mordike B (2006) Magnesium technology (metallurgy, design data, applications). Springer, Berlin

5. Kipouros G, Sadoway D (2001) A thermochemical analysis of the production of anhydrous $\mathrm{MgCl}_{2}$. J Light Metals 1(2):111-117

6. Eliezer D, Aghion E, Froes F (1998) Magnesium science, technology and applications. Adv Perform Mater 5(3):201-212

7. Das S (2008) Primary magnesium production costs for automotive applications. JOM 60(11):63-69

8. Kramer D (2001) Magnesium, its alloys and compounds. U.S. Geological Survey, Reston, VA

9. O'Mara W, Herring R, Hunt L (1990) Handbook of semiconductor silicon technology. Noyes Publications, Saddle River, NJ

10. Gupta C, Krishnamurthy N (2005) Extractive metallurgy of rare earths. CRC Press, Boca Raton, FL

11. Daane AH, Spedding FH (1953) Preparation of yttrium and some heavy rare earth metals. J Electrochem Soc 100(10):442-444 
12. U.S. Energy Requirements for Aluminum Production (2007) U.S. Department of Energy, EERE Report

13. U.S. Environmental Protection Agency (2012) Overview of greenhouse gases. [Online]. http://epa.gov/climatechange/ghge missions/gases/fgases.html

14. Schmidt-Hatting W, Huwyler S (1971) Electrolytic cell apparatus. U.S. Patent 3,578,580

15. Ginsberg H, Siefrid W (1975) Verfahren und Vorrichtung zur schmelzfluselektrolytischen Reduktionvon Metalloxiden zu ihren Metallen. German Patent 19,48,462

16. Minck R (1978) Method and apparatus for separating a metal from a salt thereof. U.S. Patent 4,108,743

17. Rapp R (1999) Method and apparatus featuring a non-consumable anode for the electrowinning of aluminum. U.S. Patent 5,942,097

18. LaCamera A, Ray S (2001) Electrolysis in a cell having a solid oxide ion conductor. U.S. Patent 6,187,168

19. Krishnan A, Lu XG, Pal UB (2005) Solid oxide membrane process for magnesium production directly from magnesium oxide. Metall Mater Trans B 36(4):463-473

20. Krishnan A, Lu XG, Pal UB (2005) Solid oxide membrane (SOM) technology for environmentally sound production of tantalum metal and alloys from their oxide sources. Scand J Metall 34(5):293-301

21. Guan X, Pal UB, Gopalan S, Powell AC (2013) LSM (La0.8Sr0.2MnO3)-inconel inert anode current collector for solid oxide membrane (SOM) electrolysis. J Electrochem Soc 160(11):F1179-F1186

22. Guan X, Pal UB, Powell AC (2014) Energy-efficient and environmentally friendly solid oxide membrane electrolysis process for magnesium oxide reduction: experiment and modeling. Metallurg Mater Trans E 1(2):132-144

23. Gratz ES, Guan X, Milshtein JD, Pal UB, Powell AC (2014) Mitigating electronic current in molten flux for the magnesium SOM process. Metallurg Mater Trans B 45(4):1325-1336

24. Guan X, Su S, Pal UB, Powell AC (2014) Periodic shorting of SOM cell to remove soluble magnesium in molten flux and improve faradaic efficiency. Metallurg Mater Trans B 45(6):2138-2144

25. Guan X, Zink PA, Pal UB, Powel AC (2013) Recycling of magnesium alloy employing refining and solid oxide membrane (SOM) electrolysis. Metallurg Mater Trans B 44(2):261-271

26. Guan X, Pal UB, Powel AC (2013) An environmentally friendly process involving refining and membrane-based electrolysis for magnesium recovery from partially oxidized scrap alloy. JOM 65(10): 1285-1292

27. Su S, Guan X, Pal U (2015) Zero-carbon-emission aluminum production by solid oxide membrane based electrolysis process. (Paper presented at the TMS Annual Meeting and Exhibition, Orlando, FL, March 15-19, 2015.)

28. Suput M, DeLucas R, Pati S, Ye G, Pal U, Powell A (2008) Solid oxide membrane technology for environmentally sound protection of titanium. Min Proc Extract Metall 117(2):118-122

29. Pati S, Suput M, Delucas R, Pal UB (2008) Solid oxide membrane process for calcium production directly from its oxide. In: EPD Congress 2008, TMS, Warrendale, PA

30. Martin A, Lambertin D, Poignet J-C, Allibert M, Bourges G, Pescayre L, Fouletier J (2003) The electrochemical deoxidation of metal oxides by calcium using a solid oxide membrane. JOM 55(10):52-54

31. Pal UB, Powell AC IV (2007) The use of solid-oxide-membrane technology for electrometallurgy. JOM 59(5):44-49

32. He L, Lu X-G, Chen C-Y, Li Q, Li C-H, Zhong Q-D (2008) Metal niobium by solid oxygen-ion membrane. Chin J Nonferr Met 18(7):1336-1341

33. Jiang Y, Zink PA, Pal UB (2012) Solid oxide membrane process for the reduction of uranium oxide surrogate in spent nuclear fuel. ECS Trans 41(33):171-180
34. Jiang Y, Xu J, Guan X, Pal UB, Basu SN (2013) Production of silicon by solid oxide membrane-based electrolysis process. Mater Res Symp Proc 1493:231-235

35. Zhao B, Lu X, Zhong Q, Li C, Chen S (2010) Direct electrochemical preparation of CeNi5 and $\mathrm{La}_{x} \mathrm{Ce}_{1-x} \mathrm{Ni}_{5}$ alloys from mixed oxides by SOM process. Electrochim Acta 55:2996-3001

36. Ye XS, Lu XG, Li CH, Ding WZ, Zou XL, Gao YH, Zhong QD (2011) Preparation of TieFe based hydrogen storage alloy by SOM method. Int J Hydrogen Energy 36:4573-4579

37. Lu X, Zou X, Li C, Zhong Q, Ding W, Zhou Z (2012) Green electrochemical process solid-oxide oxygen-ion-conducting membrane (SOM): direct extraction of Ti-Fe alloys from natural ilmenite. Metallurg Mater Trans B 43B:503-512

38. Zou X, Lu X, Zhou Z, Li C (2012) Direct electrosynthesis of Ti5Si3/TiC composites from their oxides/C precursors in molten calcium chloride. Electrochem Commun 21:9-13

39. Zou X, Lu X, Li C, Zhou Z (2010) A direct electrochemical route from oxides to Ti-Si intermetallics. Electrochim Acta 55:5173-5179

40. Kinov P, Tivchev P (2013) Revision hip arthroplasty: management of bone loss. In: Arthroplasty-update, Intech, p. 317

41. U.S. Geological Survey (2015) Mineral commodity summaries. Reston, VA

42. Haie J (2006) Boeing 787 from the ground up, Aero Magazine, Boeing, 4th quarter, pp. 17-23

43. Jones N (2011) Materials science: the pull of stronger magnets. Nature 472:22-23

44. Sugimoto S (2011) Current status and recent topics of rare-earth permanent magnets. J Phys D 44(6):1-11

45. Goetzberger A, Hebling C (2000) Photovoltaic materials, past, present, future. Sol Energy Mater Sol Cells 62:1-19

46. Pal UB (2009) Oxygen-producing inert anodes for SOM process. United States Patent 2009/0000955 A1

47. Filal M, Petot C, Mokchah M, Chateau C, Carpentier JL (1995) Ionic conductivity of yttrium-doped zirconia and the "composite effect". Solid State Ion 80:27-35

48. Baird J, King T, Stein C (1999) Diffusion of oxygen in silver. J Phys Chem Solids 60:891-894

49. Jiang SP (2008) Development of lanthanum strontium manganite perovskite cathode materials of solid oxide fuel cells: a review. J Mater Sci 43(21):6799-6833

50. Gratz ES, Guan X, Milshtein JD, Pal UB, Powell AC (2014) Mitigating electronic current in molten flux for the magnesium SOM process. Metall Mater Trans B 45(4):1325-1336

51. Li J, Lu X-J, Lai Y-Q, Li Q-Y, Liu Y-X (2008) Research progress in $\mathrm{TiB}_{2}$ wettable cathode for aluminum reduction. JOM 60(8):32-37

52. Xu J, Lo B, Jiang Y, Pal U, Basu S (2014) Stability of yttria stabilized zirconia in molten oxy-fluorite flux for the production of silicon with the solid oxide membrane process. J Am Ceram Soc 34(15):3887-3896

53. Duffy JA (1996) Optical basicity: a practical acid-base theory for oxides and oxyanions. J Chem Educ 73(12):1138-1142

54. Duffy J (1993) A review of optical basicity and its applications to oxidic systems. Geochim et Cosmochim 57:3961-3970

55. Duffy J (1989) Optical basicity of titanium (IV) oxide and zirconium (IV) oxide. J Am Ceram Soc 72(10):2012-2013

56. Gratz E, Milshtein J, Pal U (2013) Determining yttria-stabilized zirconia (YSZ) stability in molten oxy-fluoride flux for the production of magnesium with the SOM process. J Am Ceram Soc 96(10):3279-3285

57. Mukherjee A, Campagnol N, Dyck JV, Fransaer J, Blanpain B (2015) Compatibility issues of yttria-stabilized zirconia solid oxide membrane in the direct electro-deoxidation of metal oxides. J Am Ceram Soc 98(3):972-981

58. Mills K (2011) The estimation of slag properties. In: Southern African Pyrometallurgy, Misty Hills 
59. Schiefelbein S, Sadoway D (1997) A high-accuracy, calibrationfree technique for measuring the electrical conductivity of molten oxides. Metall Mater Trans B 28B:1141-1149

60. Pal UB (2002) Determining physio-chemical properties of slags by electrical measurements. JOM 54(11):57-61

61. Quested PN, Monaghan BJ (2001) The measurement of thermophysical properties of molten slags and fluxes. High Temp Mater Processes (London) 20(3-4):219-233

62. Krishnan A (2006) Solid oxide membrane process for the direct reduction of magnesium from magnesium oxide. PhD Dissertation, Boston University, Boston, MA

63. Roine A (2002) HSC chemistry, Outokumpu Research Oy, Pori, Finland

64. U. S. A. M. P. (USAMP) (2006) Magnesium vision 2020: A North American automotive strategic vision for magnesium. United States Council For Automotive Research (USCAR), Southfield, MI

65. Pollock TM (2010) Weight loss with magnesium alloys. Science 328:986-987

66. Bullis K (2014) A cleaner, cheaper way to make metals, MIT technology review. [Online]. http://www.technologyreview.com/ news/527526/a-cleaner-cheaper-way-to-make-metals/
67. Chen GZ, Fray DJ, Farthing TW (2000) Direct electrochemical reduction of titanium dioxide to titanium in molten calcium chloride. Nature 407:361-364

68. Milshtein J, Gratz E, Pati S, Powell AC, Pal U (2013) Yttria stabilized zirconia membrane stability in molten fluoride fluxes for low-carbon magnesium production by the SOM process. J Min Metall Sect B 49(2):183-190

69. Martin A, Poigner JC, Fouletier J, Allibert M, Lambertin D, Bourges G (2010) Yttria-stabilized zirconia as membrane material for electrolytic deoxidation of $\mathrm{CaO}-\mathrm{CaCl}_{2}$ melts. J Appl Electrochem 40:533-542

70. Gao Y, Duan C, Yang Y, Ruan D, Yang C, Hong C (2015) Effect of basicity on electroreduction with controlled oxygen flow of molten slag containing FeO. J Sustain Metall 1(4):275-285

71. Guan X, Pal UB (2015) Design of optimum solid oxide membrane electrolysis cells for metals production. Prog Nat Sci 25(6):591-594 